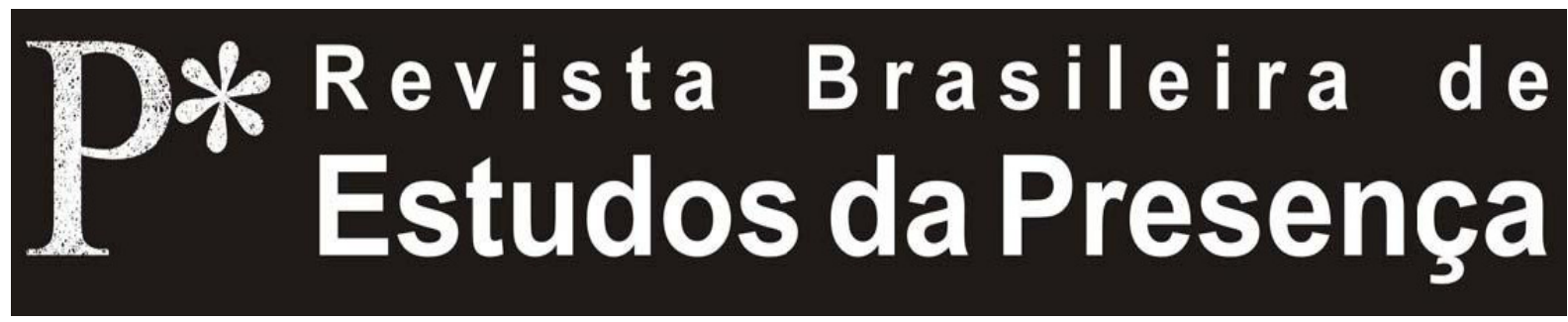

DOI - http://dx.doi.org/10.1590/2237-266025031

ISSN 2237-2660

\title{
As Interpretaçoes do Sistema Delsarte no Teatro Russo e Soviético dos Anos 1910-1920
}

\author{
Marie-Christine Autant-Mathieu \\ Centre National de la Recherche Scientifique, CNRS - Paris, França \\ Université Sorbonne Nouvelle Paris III - Paris, França
}

\begin{abstract}
RESUMO - As Interpretações do Sistema Delsarte no Teatro Russo e Soviético dos Anos 1910-1920 ${ }^{1}$ - Para um grande número de estudiosos anglo-saxões, os ensinamentos de François Delsarte encontram ecos na Rússia, no trabalho de Stanislavski, Vakhtangov e Mikhaïl Tchekhov. A procura por correspondências entre a emoção e o gesto implica uma concepção orgânica do ato criador. Visto, entretanto, a partir da União Soviética-Rússia, Delsarte é, ao contrário, o pai de uma nova antropologia do ator-máquina. O objetivo deste artigo é atualizar os mal-entendidos que distorceram os dados e mostrar que, na Rússia, a transmissão seguiu caminhos que desviaram a orientação na recepção do sistema de Delsarte.

Palavras-chave: François Delsarte. Teatro Russo. História do Teatro. Ator. Corpo.
\end{abstract}

ABSTRACT - The Interpretations of the Delsarte System in Russian and Soviet Theatre in the 1910s and 1920s - According to a number of Anglo-Saxon scholars, François Delsarte's ideas had repercussions in Russia, in the work of Stanislavski, Vakhtangov and Mikhaill Tchekhov. The search for correspondences between emotion and gesture implies an organic conception of the creative act. From a Soviet/Russian point of view, Delsarte is regarded, however, as the father of a new anthropology of actor-machine. The goal of this article of to shed light on the misunderstandings that distorted the data, and show that in Russia their dissemination happened in ways that modified the manner the Delsarte system was received.

Keywords: François Delsarte. Russian Theatre. Theatre History. Actor. Body.

RÉSUMÉ - Les Interprétations du Système Delsarte sur la Scène Russe et Soviétique dans les Années 1910-1920 - Pour nombre d'exégètes anglo-saxons, l'enseignement de François Delsarte trouve des échos, en Russie, du côté de Stanislavski, Vakhtangov et Mikhaïl Tchekhov. La quête de correspondance entre l'émotion et le geste traduit une conception organique de l'acte créateur. Vu d'Union soviétique-Russie, Delsarte est tout au contraire le père d'une nouvelle anthropologie de l'acteur-machine. L'objet de cet article est de mettre à jour les malentendus qui ont faussé les pistes et de montrer qu'en Russie, la transmission a suivi des voies qui ont infléchi la réception du système de Delsarte.

Mots-clès: François Delsarte. Théâtre Russe. Histoire du Théâtre. Acteur. Corps. 
Não há uma corrente Delsarte, há antes uma radioatividade Delsarte ${ }^{2}$.

Para muitos exegetas europeus e norte-americanos, o ensinamento de François Delsarte encontra ecos na Rússia, no que diz respeito ao trabalho de Konstantin Stanislavski, Evguéni Vakhtangov e Mikhaïl Tchekhov ${ }^{3}$. A busca pela correspondência entre a emoção e o gesto traduz uma concepção orgânica do ato criador, ao passo que a emoção interior encontra sua expressão no âmbito de uma observação das leis da natureza. Insiste-se sobre o fato de que Jerzy Grotowski, que ampliou o sistema de Stanislavski a partir das ações físicas, apreciou a relevância dada por Delsarte ao homem em sua totalidade, a importância dada às "reações introvertidas e extrovertidas no contato humano" e o lugar reservado aos exercícios ${ }^{4}$.

Visto da União Soviética-Rússia, Delsarte é, ao contrário, pai de uma nova antropologia do ator-máquina. Desde Vladimir Gardine, ao passar por Lev Koulechov e Serge Eisenstein, é no cinema que ele possuiria um impacto maior. Em outras áreas (teatro, música e dança), seu sistema é, por vezes, citado como fonte das leis do movimento segmentado, coordenado e racionalizado, enquanto os gestos disciplinam e canalizam as emoções. Delsarte é colocado a serviço da vanguarda revolucionária, que preconiza a fábrica de um homem novo, são, maleável, eficaz e harmonioso.

Delsarte, como se disse muitas vezes, foi esmagado sob seu mito: a quase falta de traços escritos de seu ensinamento foi compensada por uma proliferação de obras de seus verdadeiros ou falsos discípulos. Homem paradoxal (cantor e professor de canto, interessou-se pela anatomia, pela psicologia e procurou leis para a criação artística; seus alunos eram atores, pintores, escultores, oradores, assim como músicos) e artista traído (seu sistema foi apartado de sua dimensão metafísica, embora considerasse a religião como primeiro componente, antes mesmo da arte e da ciência; foi também frequentemente amputado de sua dimensão semiótica, em prol de uma focalização nas leis do movimento), Delsarte, esse sujeito de Louis-Philippe e de Napoleão III, poderia ter imaginado que sua herança iria ali- 
mentar a dança moderna ocidental, a euritmia suíça e alemã, a cinemontagem soviética, assim como o comércio higienista e medical norte-americano?

Os férteis equívocos deformam os rastros e abrem um imenso campo à invenção. Delsarte parece ter herdeiros nos mais diversos países e nas mais variadas áreas. Entretanto, o que escondem essas filiações aleatórias, essas aproximações apressadas, essas pseudossimilitudes? Na Rússia, a transmissão seguiu caminhos que infletiram a recepção do seu Sistema. Para mostrar isso, é essencial evocar primeiro o passador, Sergueï Volkonski, autor da primeira e única obra de interpretação do Sistema Delsarte; posteriormente, o contexto histórico dos anos de 1910, profundamente perturbado pela primeira Guerra Mundial e pela Revolução; e, por fim, a imprecisão do seu ensinamento por si mesmo, que deixa aberta a questão da primazia da emoção ou do gesto, questão cerne nos debates russos e soviéticos, nos anos 1910 e 1920.

\section{Sergueï Mikhaïlovitch Volkonski}

O fato de uma aluna de Delsarte, a soprano Caroline Barbot, ter cantado no Mariinski de São Petersburgo, no papel de Donna Leonora na ópera La Force du destin, de Verdi, em $1862^{5}$, não contribuiu para a difusão do cantor e pedagogo francês na Rússia, país onde ele permaneceu desconhecido até 1903, data da introdução do curso de mímica e de conferências por Iouri Ozarovski (1869-1924) ${ }^{6}$. Esse ator e diretor do Teatro Aleksandrinski, Professor no Instituto Teatral de São Petersburgo, editou a revista delsartiana A Voz e o Discurso entre 1912 e 1913, complemento dos Folhetos de Ginástica Rítmica, publicados na mesma época pelo príncipe Volkonski.

Bisneto do primeiro ministro de Alexandre I, neto do dezembrista Sergueï Grigorevitch Volkonski, Sergueï Mikhaïlovitch (1860-1937) pertencia não apenas a uma família ilustre de homens de Estado e de militares, mas também de artistas (sua tia-avó, a poetisa e musicista Zinaïda Volkonskaïa, foi entoada por Pouchkine). Nas suas lembranças, publicadas após sua emigração para Paris, Volkonski explica seu interesse pela expressão corporal e vocal, pelo choque que representa para 
ele a turnê de Ernesto Rossi em Petersburgo no ano de 1877, quando ele tinha 17 anos. Ele descobre, então, a importância da expressividade (o como) da representação, em um país que valoriza o trabalho interior emocional. Grande viajante, como a maior parte dos aristocratas da época, ator e diretor amador, ele tem um conhecimento pessoal das convenções de jogos teatrais e operísticos russos, europeus e norte-americanos. Com 30 anos, seus talentos de conferencista abrem-lhe as portas dos círculos artísticos de Petersburgo e de Chicago, para onde o Ministro da Educação Popular o envia em missão, no ano de 1893, durante seis meses, a fim de falar em diversos congressos, dentre os quais um sobre as religiões. Durante essa viagem, terá ele ouvido falar sobre Delsarte? Sua curta e tumultuosa presença na direção dos teatros imperiais entre 1899 e 1901 (ele teve tempo de convidar Tommaso Salvini, introduzir uma classe de mímica e reorganizar o balé, sem, todavia, conseguir impor Serge Diaghilev) reforça sua decisão de ficar afastado da administração e da política, a fim de preservar sua liberdade de escolha e de inovação. Em 1910, dirige-se a Hellerau, onde é conquistado pela ginástica rítmica, que pratica e introduz na Rússia, inclusive no Teatro de Arte. Por intermédio de Émile Jaques-Dalcroze, Volkonski descobre Delsarte: doravante, ele promoverá a difusão entusiasta dos trabalhos do músico suíço e do cantor francês.

A sobreposição de um sistema por outro criou uma confusão que perdura até hoje na Rússia, onde os dois nomes permanecem indissoluvelmente associados, embora a conexão entre eles se justifique. Ignora-se se Dalcroze estudou os exercícios de Delsarte em Paris, nos anos 1880, e se ele teve contatos com Alfred Giraudet. É certo, no entanto, que ele fez inúmeras anotações pessoais sobre os livros de Angélique Arnaud e de Alfred Giraudet, conservados em sua biblioteca. Sabe-se ainda que o nome de Delsarte figura inúmeras vezes nas margens de seus planos de curso. Dalcroze evolui em direção às representações públicas, plásticas e musicais, enquanto Delsarte permanecera voltado para os exercícios da expressividade privada (a ginástica harmônica é atribuída a seu aluno MacKaye). Nota-se que Dalcroze introduz sua obra 
A Ginástica Rítmica (1906) por meio de uma citação da lei da correspondência de Delsarte?

Fascinado pela aliança do ritmo corporal e da música e descobrindo nesse mesmo ano a dança livre de Duncan, as composições rítmicas de Appia, os screens e a teoria da super-marionete de Craig (que foi em 1909 a Moscou para a montagem de Hamlet, representada em dezembro de 1911 no Teatro de Arte) ${ }^{8}$, Volkonski traduz em russo a obra do dalcroziano Jean d'Udine $A$ arte e o gesto, em 1912, inicia e dirige, de 1912 a 1914, cursos de ginástica rítmica em São Petersburgo e edita a revista especializada Folhetos dos cursos de rítmica ${ }^{9}$.

Em julho de 1912, enquanto trabalha em sua interpretação do sistema de Delsarte, reencontra em Paris a filha do mesmo, Marie Géraldy ${ }^{10}$. Terá ele se inspirado na obra Delsarte system of oratory, publicada em 1893? Buscou essencialmente inspiração nas obras de Genevieve Stebbins e Alfred Giraudet para escrever O homem expressivo, que é lançado em $1913 \mathrm{em}$ São Petersburgo, com numerosas ilustrações de estátuas gregas, quadros e afrescos de Rafael, Michelangelo, Caravaggio, dentre outros artistas italianos.

Após a revolução, o passado de dezembrista do seu avô salva Volkonski das perseguições bolcheviques. Ele sobrevive multiplicando as conferências e os cursos, o que contribui para uma grande difusão do sistema Delsarte nos círculos amadores e profissionais, tradicionais ou de vanguarda. No Teatro de Arte, Stanislavski the confia a formação sobre o discurso cênico no seu estúdio de ópera e vai assistir a sete de seus cursos, dos quais faz anotações ${ }^{11}$. A partir de 1917, Volkonski começa a fazer parte dos novos sócios acionistas da Confraria Cooperativa do Teatro de Arte, que substitui a antiga sociedade privada. Em abril de 1919, ele é escolhido como membro ativo da comissão artística. Apesar de sua obra A palavra expressiva ser frequentemente citada por Stanislavski como referência para os comediantes que possuem dificuldades em representar peças em verso, é na realidade $O$ Homem expressivo, livro "conforme Delsarte", que o diretor-pedagogo recomenda aos alunos de seus estúdios ${ }^{12}$. Stanislavski encontra, com efeito, paralelos entre sua própria pesquisa sobre a verdade interior 
e as aspirações de Delsarte em "[...] justificar seus efeitos logicamente; psicologicamente, tanto no que concerne ao gesto como no que tange as inflexões de sua voz ${ }^{13}$ ". No Maly, no Bolshoi, em mais de vinte estúdios dentre os quais se encontram os de Vakhtangov ${ }^{14}$ e o estúdio judeu Habima, Volkonski é o incontornável professor de expressividade corporal, de rítmica e o especialista sobre o gesto-discurso ${ }^{15}$. Entre 1919 e 1921, ele ensina no Instituto de Rítmica, criado recentemente, no Tonplaso (Associação plástico-sonora), é membro do diretório do Instituto do drama musical (antiga Filarmônica, futura GITIS). Após sua emigração em dezembro de 1921, Volkonski se estabelece em Paris, onde se torna diretor do Conservatório Russo e dá continuidade à sua atividade como crítico de arte. Não é por acaso que Mikhaïl Tchekhov, que ouviu suas conferências nos anos 1910 e 1920 em Moscou, solicita sua ajuda no outono de 1936 em seu lugar de exílio. Ele convida Volkonski para falar de Delsarte, Dalcroze e Steiner em seu estúdio teatral de Dartington Hall, no sul da Inglaterra. Uma de suas alunas, Deirdre Hurst Du Prey, lembra-se de discussões sobre "espetáculos rítmicos, partituras rítmicas de peças, a dinâmica, o tempo, as entonações rítmicas [...]" (Du Prey, 1992, p. $162-163)^{16}$.

\section{O Homem Expressivo: Delsarte interpretado por Volkonski}

Uma vez que ele está entusiasmado pelas pesquisas de Dalcroze e suas ramificações em todos os domínios da arte e mesmo no campo medicinal, por que Volkonski terá se interessado também por Delsarte? O fato é que o francês foi um dos precursores nas leis da dicção e da atuação. Dalcroze teorizou o que aplicou à formação na dança, na mímica e no jogo do ator. Da técnica, Volkonski remonta às "bases científicas", como assinala desde o prefácio ${ }^{17}$, a fim de estimular os atores e cantores a deixarem de se limitar à inspiração e à rotina. Com efeito, Volkonski coloca a semiótica de Delsarte em primeiro lugar na epígrafe de seu livro: 
A arte é o conhecimento dos processos exteriores pelos quais o homem descobre a vida, a alma e a razão; [...]. A arte é a descoberta do signo que corresponde à essência (Volkonskij, 1913, p. 6) $)^{18}$.

Nota-se que no inverno de 1911, no momento em que ele traduz Jean d'Udine e pesquisa sobre Delsarte, Volkonski encontra Stanislavski em Roma. Ele lê para o último suas notas sobre as leis do discurso cênico, enquanto o codiretor do Teatro de Arte lhe mostra os fragmentos do seu Sistema. Essa vontade convergente da maior parte dos artistas da época de encontrar leis para a arte caracteriza a entrada no século XX e a emergência de novas disciplinas científicas. No fundo, Delsarte é descoberto na Rússia em um momento propício, quando o teatro, a dança e, posteriormente, o cinema, mais do que a música ou o canto, se inscrevem em um debate sobre as relações entre a arte e a ciência. Com pouco mais de dez anos, entre 1910 (data de abertura do Hellerau), 1919 (data da criação do primeiro estúdio de cinema soviético) e 1921 (data dos primeiros espetáculos biomecânicos de Vsevolod Meyerhold), o corpo do artista está no centro da observação: seu corpo, e não mais unicamente sua dicção (formação tradicional na recitação dos cursos de arte dramática) ou sua emoção (desde Mikhaïl Chtchepkine, a escola russa se define contra Denis Diderot e Benoît Constant Coquelin, por uma atuação baseada nos sentimentos experimentados, diríamos com Stanislavski psicológica).

Volkonski apoia sua interpretação do sistema Delsarte em uma bibliografia largamente alimentada de fontes americanas, inglesas, alemãs e francesas ${ }^{19}$ : O Homem expressivo se quer e será uma obra de referência. Depois de ter mostrado a notoriedade de Delsarte durante sua vida, evocado os detalhes biográficos necessários para compreender as motivações de sua pesquisa e feito a parte do que pertence ao mestre e do que foi adicionado por seus alunos ${ }^{20}$, Volkonski se volta para a exposição detalhada do método; descreve a tríade e suas correspondências corporais: vida (a respiração, ligada à sensação), alma (a laringe e o timbre, ligados à emoção), razão (a boca e as palavras, ligadas ao pensamento). Ao ignorar a di- 
mensão religiosa, isto é, a filosofia do sistema, ele enumera as interações tripartidas (físico, mental, moral; exterior, interior, superior; excêntrico, concêntrico, normal), seus domínios de aplicação (ciência, virtude, natureza), suas funções induzidas (distinguir, reunir, afirmar).

Ele examina sucessivamente os elementos das oitenta e uma expressões faciais que são a base dos exercícios e inscreve o estudo do gesto menos no sistema absoluto de correspondências que na estática (leis de equilíbrio e resistência) e na dinâmica (nove leis de movimento: altura, força, direção/ extensão, sucessão, oposição, forma, velocidade, reação, duração) ${ }^{21}$, insistindo na harmonia (respeito das prioridades e das combinações). Sua apresentação não possui nada de dogmático e não implica nenhum determinismo do gesto ${ }^{22}$.

Encontra-se em seu livro um conceito que será transformado por M. Tchekhov em uma das chaves do seu método, o "gesto psicológico" (GP) ${ }^{23}$. Esse não está ligado à necessidade da ação, mas recebe algum sentido a partir do centro, no qual ele se enraíza (barriga, epigástrio, peito). Para Tchekhov, esse gesto significará ao mesmo tempo o gesto em si, visível ou virtual, e os sentimentos que estão associados ao mesmo ${ }^{24}$. Nem ilustrativo nem mecânico, o GP tchekhoviano expressa o todo do personagem e lhe garante uma dimensão metafísica, remetendo a esta "verdade misteriosa ${ }^{25}$ ", da qual já falava Delsarte ${ }^{26}$. Contudo, sob a influência da euritmia e da antroposofia steineriana, Tchekhov situa o gesto psicológico tanto no corpo quanto na linguage $\mathrm{m}^{27} \mathrm{e}$ o religa a um bom treinamento da imaginação - se distinguindo claramente, nesse sentido, de Delsarte:

$\mathrm{O}$ ator bem treinado e tecnicamente formado para visualizar e efetuar os gestos psicológicos [...] regozija-se nessa vida caleidoscópica e efervescente de imagens, de gestos e de intenções [...] (Chekhov, 1996, p. 114) ${ }^{28}$.

Volkonski fecha seu livro com esta súplica:

$\mathrm{O}$ acordo com a natureza: eis a base do saber-fazer que nos ensina Delsarte. $\mathrm{O}$ acordo com a natureza e não o acordo com os hábitos estabelecidos e as práticas do palco (Volkonskij, 1913, p. 167) ${ }^{29}$. 
No início do ano de 1910, esse livro reforça a posição dos partidários de uma arte livre das convenções e dos clichês, natural, entretanto, baseada em conhecimentos reunidos em uma técnica, em exercícios. Volkonski distingue o que é inato e o que devemos conhecer de modo consciente do que é aprendido e que deve estar integrado como uma segunda natureza:

\begin{abstract}
No palco, não penseis nas regras e nas leis, essas devem estar em vós, elas terão valor apenas se tiverem se tornado inconscientes. [...] Quanto mais pensardes durante os exercícios, menos tereis de pensar durante a representação (Volkonskij, 1913, p. 9) .
\end{abstract}

Para ele, a arte não imita a natureza, mas reproduz a vida com a ajuda da natureza assujeitada ${ }^{31}$. Em uma carta inédita de Volkonski endereçada a Stanislavski em 1913 - para acompanhar $O$ homem expressivo, que estava lhe oferecendo - tornase visível como o livro se situa no cenário teatral da época, no qual o Teatro de Arte e seu modo de atuação possuem um papel predominante:

Eu reconheço, hesito em lhe fazer lê-lo: o sistema do qual vos falo constitui uma abordagem diferente da vossa. No entanto, a pesquisa visa à mesma coisa: a verdade da vida na representação. Se, por um lado, parece que a mecanicidade domina o sentimento, isso é apenas uma aparência sem fundamento. Confira os dois últimos capítulos: um último conselho e conclusão (Volkonskij, carta s. p., 1911) $)^{32}$.

\title{
Volkonski acrescenta:
}

Não considero isso como uma magnífica ginástica artística dos órgãos do corpo, incitados a "expressar". Como o rosto pode exprimir aquilo que sinto se os músculos [que o compõem] não se submetem ao meu sentimento? (Volkonskij, carta s. p., 1911) ${ }^{33}$.

As angústias de Volkonski tinham fundamento, pois certas passagens do livro nos levam a uma outra análise. Com efeito, a codificação e a sistematização dos efeitos da emoção, tais como eles se manifestam no corpo humano através do 
gesto e da palavra ${ }^{34}$, a descrição precisa das zonas-termométricas $^{35}$, a lista das partes expressivas do corpo (olho, boca, nariz, cabeça, pescoço, ombros, tronco, braço, mão, pernas) seguida de exercícios adaptados para cada caso, toda essa nomenclatura servirá como base de reflexão para praticar a divisão e a montagem que os cineastas soviéticos irão experimentar e teorizar a partir de 1919, data da criação da escola de cinema do Estado.

\section{O Percurso do Delsartismo na URSS nos Anos 1920}

A partir de 1917, o poder bolchevique se esforça em formar cidadãos pensantes, que trabalhem, produzam, se comportem de maneira diferente dos pertencentes ao antigo regime. Interrompidas por quase cinco anos por causa das guerras, mundial e civil, as pesquisas que ligavam a arte e a ciência recomeçam ainda mais fortes, encorajadas pela filosofia materialista que sustenta, a partir de agora, todas as atividades. Nesse contexto, o livro de Volkonski tomará outra ressonância, ainda mais porque o antigo príncipe, que se tornara um trabalhador comum, ensina nos feudos artísticos de esquerda revolucionária (os estúdios de Proletkult, a escola de cinema do Estado, os teatros do Exército Vermelho, as novas escolas de ritmo e plástica musical) ${ }^{36}$.

Ao confundir o Delsarte apresentado por Volkonski com o próprio Volkonski - autor de várias obras sobre a palavra expressiva, as regras do discurso, a técnica do ator, a estética da pantomímica, da música e do balé -, as vanguardas dos anos 1920 usam o livro no combate contra a psicologia no ato da criação. Elas pretendem, com isso, promover outra estética, anti-stanislavskiana, materialista, segundo a qual os movimentos não são a expressão das emoções, mas os elementos constitutivos de um processo de trabalho. Meyerhold declarou, durante uma conversa com seus estudantes sobre a biomecânica, em 1922:

Ao invés da teoria da memória afetiva e da atuação visceral que conduzem (por causa do desconhecimento da construção do corpo humano) a efusões psicológicas, o Instituto Teatral ${ }^{37}$ criará um modelo de homem 
organizado, formando o ator em ciências exatas; de um lado, desenvolvendo e treinando o intelecto; e, de outro, desenvolvendo a aprendizagem através do esporte e da biomecânica [...] (Ejzenštejn, 2005, p. 127) ${ }^{38}$.

Algumas vezes, o vínculo com Delsarte é evidentemente revelado, como foi o caso da pesquisa coreográfica do Instituto do ritmo de Petrograd, no qual em fevereiro de 1922 ocorreu uma demonstração de exercícios plásticos e musicais inspirados em Delsarte. Seu sistema cimenta também as experimentações do Estúdio da Arte Única, dirigido por Daria Moussinova-Ozarovskaïa, em ruptura com o balé tradicional e fundamentado em uma busca de universalidade (pelo trabalho com os ritmos e os gestos interiores) e de síntese (o ritmo coordena, une e orienta os elementos de todas as artes).

No cinema essa herança foi também reconhecida. Vladimir Gardine, desde 1916, se encanta por Delsarte. Na escola de cinema, Gardine propõe a seus alunos quadros próximos daqueles de Delsarte para trabalhar os planos ${ }^{39}$, ele elabora um método de análise do movimento cênico a partir da divisão e da combinação dos movimentos e elabora 1245 composições para a disposição da cabeça com base no modelo das 1245 composições de Delsarte para as mímicas. Lev Koulechov, delsartiano ortodoxo de 1918 a 1922, segue por esse mesmo caminho, desprezando, entretanto, a mística e a semiótica conservadas por Gardine. Ele mantém somente as divisões e as associações e desenvolve, dessa forma, sua teoria da montagem $^{40}$ (observemos que, desde 1914, Volkonski nos incita a utilizar o filme como meio de anotação coreográfica, as "partes-movimentos", que são como notas sobre uma partitura, podendo ser aprendidas e reproduzidas (Jampol'skij, 1991, p. $190)^{41}$; essa aplicação, que nunca vingou, anuncia a montagem que nasce do corpo humano e registra os movimentos como a expressão mecânica do ritmo natural).

No teatro, o vínculo com esse autor é mais difuso. A seguinte citação de Delsarte, retirada de $O$ Homem expressivo: "O corpo é o instrumento, o ator é o instrumentalista ${ }^{42}$ ", como também a comparação do ator a um "homem-máquina", uma máquina que certamente é animada pelos sentimentos, mas 
que permanece submissa às leis gerais da mecânica ${ }^{43}$, serão interpretadas como um convite à utilização mecanicista do sistema, um eco da fórmula de Meyerhold na base da biomecânica de 1921: N (o ator) = A1 (o construtor) + A2 (o corpo do ator).

Em 15 de novembro de 1921, em um curso sobre o espaço teatral, Eisenstein evoca Delsarte nas notas que fizera durante o aprendizado com Meyerhold, que aconteceu da primavera de 1921 até janeiro de 1924. Para Delsarte, o equilíbrio do corpo é essencial. O gesto é menos importante do que a posição correta que, no espaço, permite trabalhar o raccourci ${ }^{44}$. Embora Meyerhold, em seu curso sobre a biomecânica, tenha se apoiado na tríade: intenção, equilíbrio e execução, e insistido no trabalho com as diferentes partes do corpo: as mãos, os olhos e a boca, entre outros ${ }^{45}$, ele não lança mão do sistema de Delsarte, que teria conhecido primeiramente pelo intermédio de Isadora Duncan em 1908, cinco anos antes de ler o livro de Volkonski. Em algumas notas preparatórias para uma conferência em Berlim, no mês de abril de 1930, o nome de Delsarte, logo seguido do nome de Laban, aparece acompanhado do seguinte comentário, conciso: "ingênua fusão da palavra e do movimento ${ }^{46}$ ". A biomecânica de Meyerhold possui outras origens, inspira-se particularmente na "ginástica natural" de Piotr Lesgaft (1837-1909) ${ }^{47}$. Para retomar o período teatral de Eisenstein, mencionar-se-á o artigo que ele escreveu com Sergueï Tretiakov em 1923 sobre "o movimento expressivo" a partir das teses de Rudolf Bode e de Ludwig Klages, que não foi divulgado. À biomecânica meyerholdiana, que ele considera próxima demais do balé (e que é, com efeito, executada na música, frequentemente nas composições de Scriabine), ele opõe a "bimecânica", resultante de um conflito entre o instinto e a vontade, entre os reflexos inconscientes e a consciência ${ }^{48}$ e, posteriormente, a "biodinâmica", nos anos 1930. 


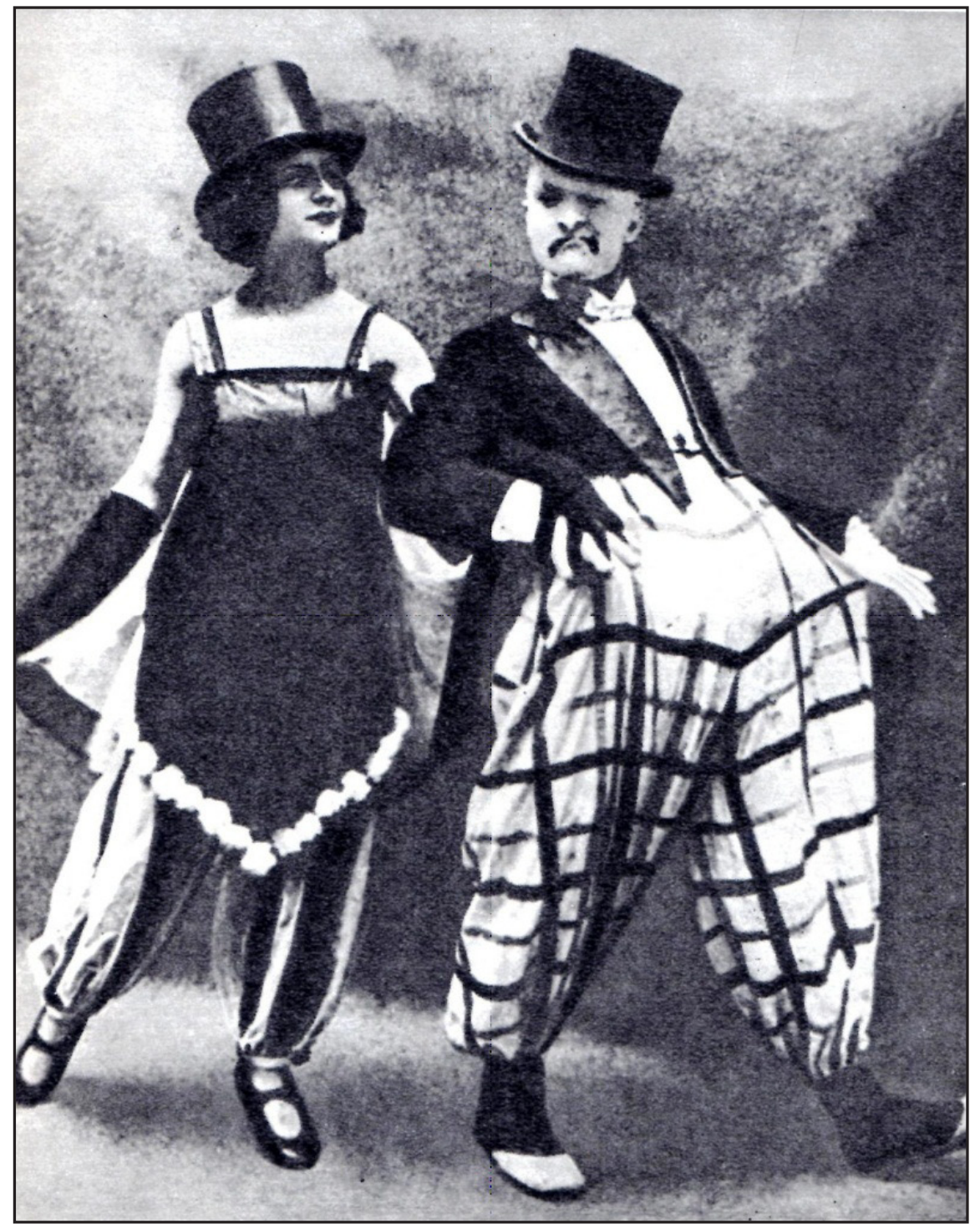

Figura 1 - O Sábio, segundo A. Ostrovski, realizado por S. Eisenstein, Teatro de Proletkult, 1923.

Mais próximo talvez que Meyerhold dos ensinamentos delsartianos esteja Alexandre Taïrov que, desde a fundação do Théâtre de Chambre em 1914, interessa-se pela pantomima e por toda forma de gesto expressivo, e também coreográfico ou ginástico. Na sua obra publicada em 1921, Notas de um diretor, discurso em defesa do ator, Taïrov acorda uma grande importância à disciplina do corpo, da respiração e da voz. Ele cita um exemplo dado por Delsarte da má gestão da emoção, que se traduz por uma tremedeira ridícula das pernas em um momento patético ${ }^{49}$. 


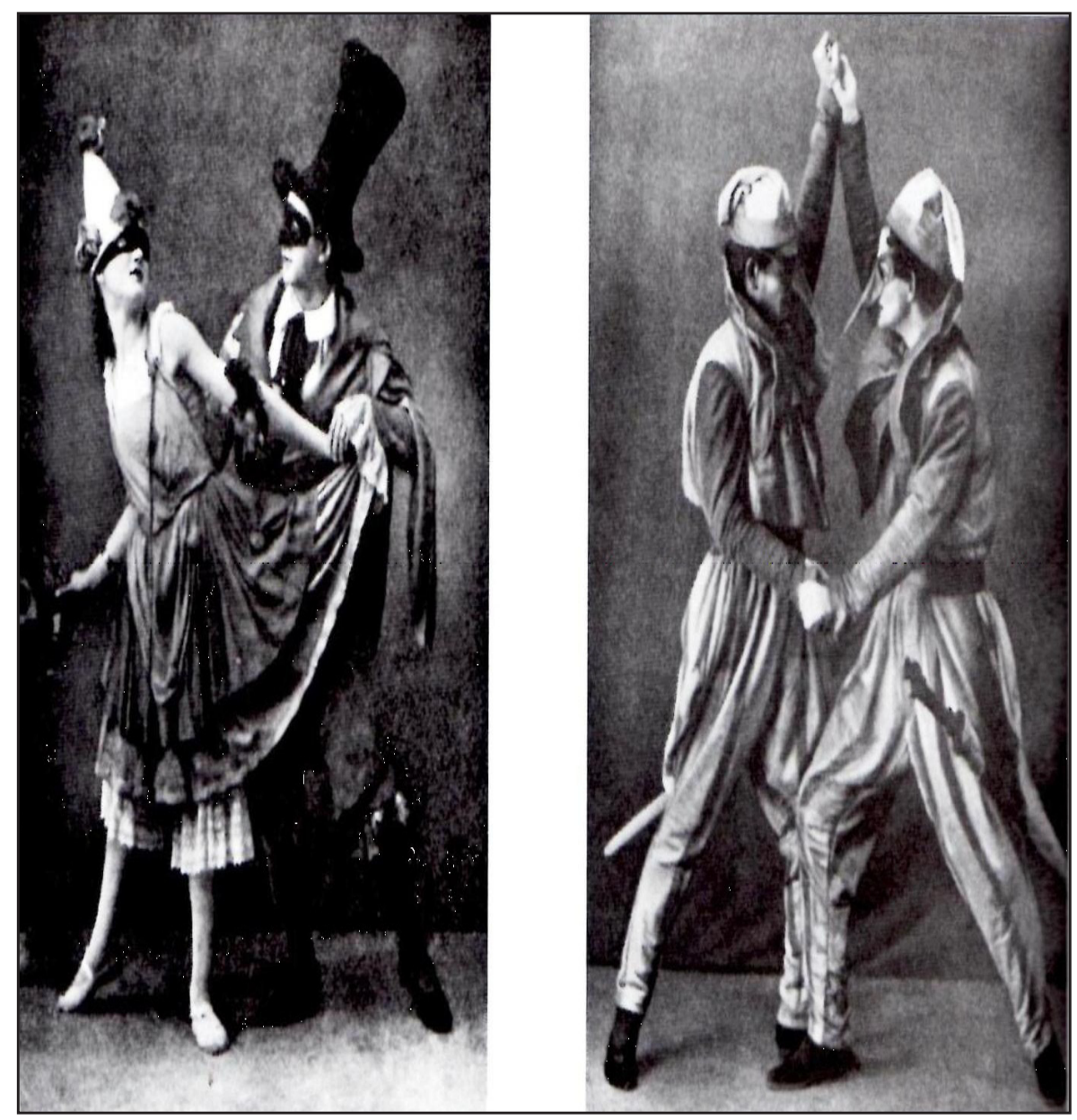

Figura 2 - Princesa Brambilla de E. T. A. Hoffmann, realizado por A.

Taïrov, Théâtre de Chambre de Moscou, 1920. Cena de carnaval.

Propagador da taylorização do gesto teatral e menos conhecido que Meyerhold, do qual ele foi assistente nas experiências biomecânicas, Ippolit Sokolov admira em $O$ Homem Expressivo um "Delsarte industrial ${ }^{50 "}$, útil para a sociedade soviética: "O teatro pode nos ensinar a andar e a gesticular, a falar uma nova língua, econômica, precisa, categórica e eficaz. O teatro é a fábrica do estilo de nossa época" (Sokolov, 1922 apud Civjan, 2010, p. 135) ${ }^{51}$. No âmbito do construtivismo, o ator, ao invés de ser o vetor de forças superiores e um meio de elevar a alma por servir ao belo e ao bem (segundo Lev Tolstoï ou Stanislavski), deve se tornar um modelo de saúde, de velocidade, de produção de efeitos úteis e se comportar no palco como uma máquina perfeita. O ritmo é a projeção da 
energia natural controlada e das impulsões. Sokolov recusa a euritmia dalcroziana, pois essa "simples pantomima aplicada à música" é impossível de ser utilizada pelo trabalhador (o poeta Alekseï Gastev, fundador do Instituto Central do Trabalho, que opera em estreita relação com a educação e a criação artística, pensa também que a música torna os corpos insossos, abate-os em vez de galvanizá-los). Sokolov preconiza a geometria das emoções, a racionalização dos movimentos, privilegiando as linhas retas. Esse neodelsartismo proporia uma coordenação, uma gesticulação industrial e uma ginástica do trabalho.

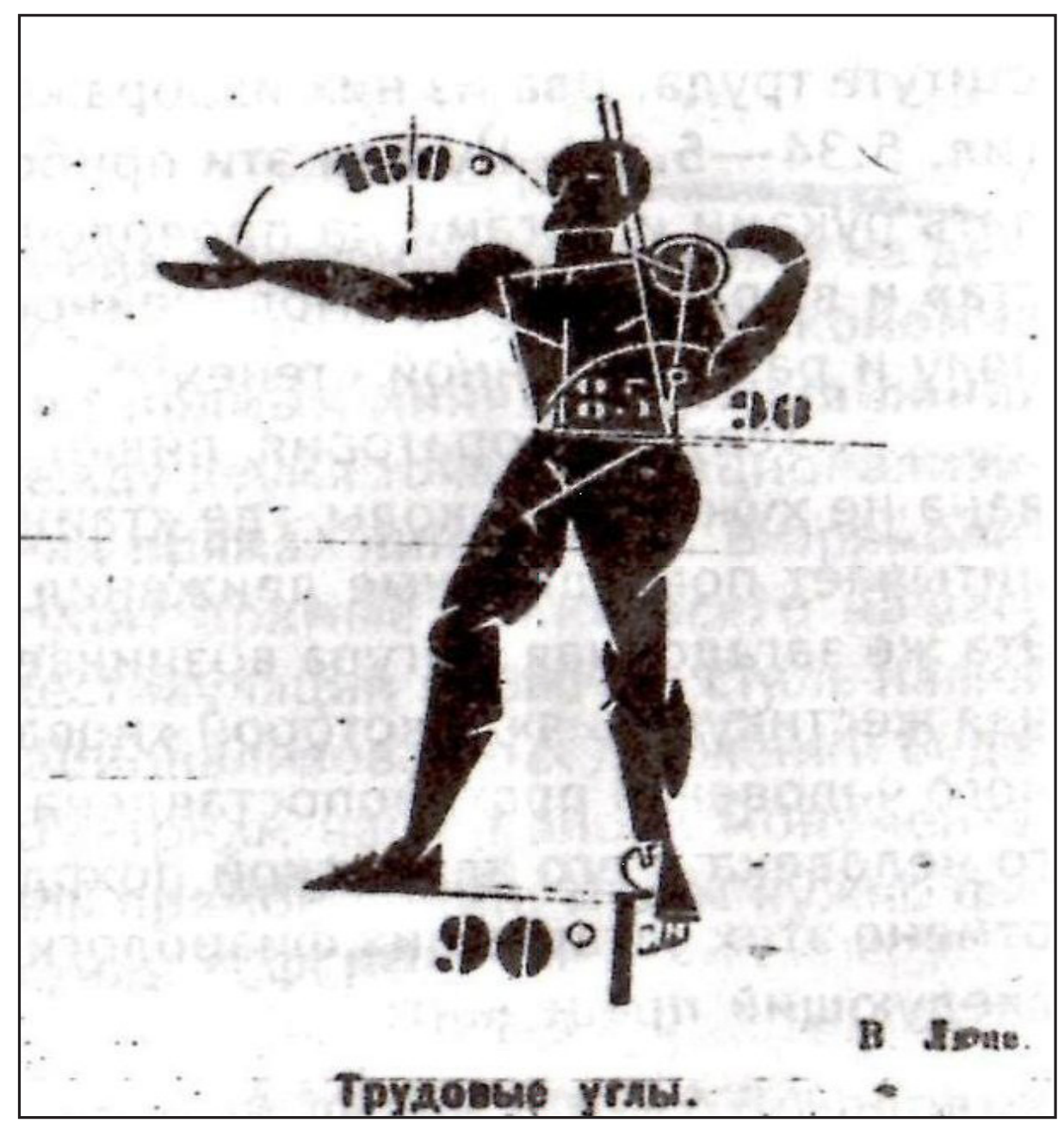

Figura 3 - Ippolit Sokolov, O gesto taylorizado, in Zrelišča, $1922^{52}$.

Dentre os ecos longínquos e deformados do delsartismo, mencionar-se-ão as pesquisas que foram conduzidas sobre o excentrismo no teatro por Grigori Kozintsev, Sergueï Ioutke- 


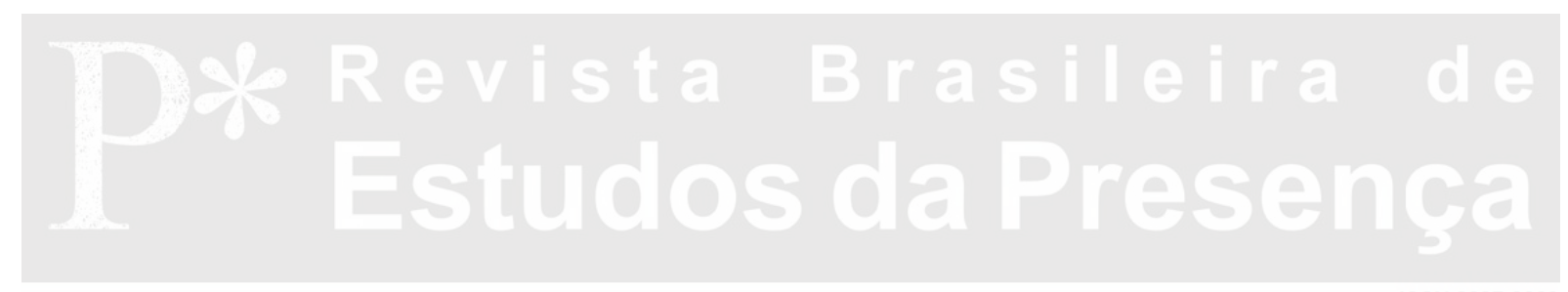

vitch e Leonid Trauberg na FEKS (Fábrica do ator excêntrico) entre 1922 e 1924, ou o "tefiztrenaj", sistema de treinamento teatral-físico criado por Nikolaï Forreger no seu ateliê de Moscou. O barão Von Greïfenthurn, de acordo com Forreger, inicia sua carreira, antes da revolução, no cabaré $O$ Espelho Curvo, trabalha algum tempo junto de Taïrov e cria, então, o efêmero Mastfor (1921-1924), no qual cultiva um ecletismo em voga na época, misturando o teatro de feira, a comédia de máscaras, o music hall, o circo e a paródia. Conhecido por sua "dança das máquinas" (1922),

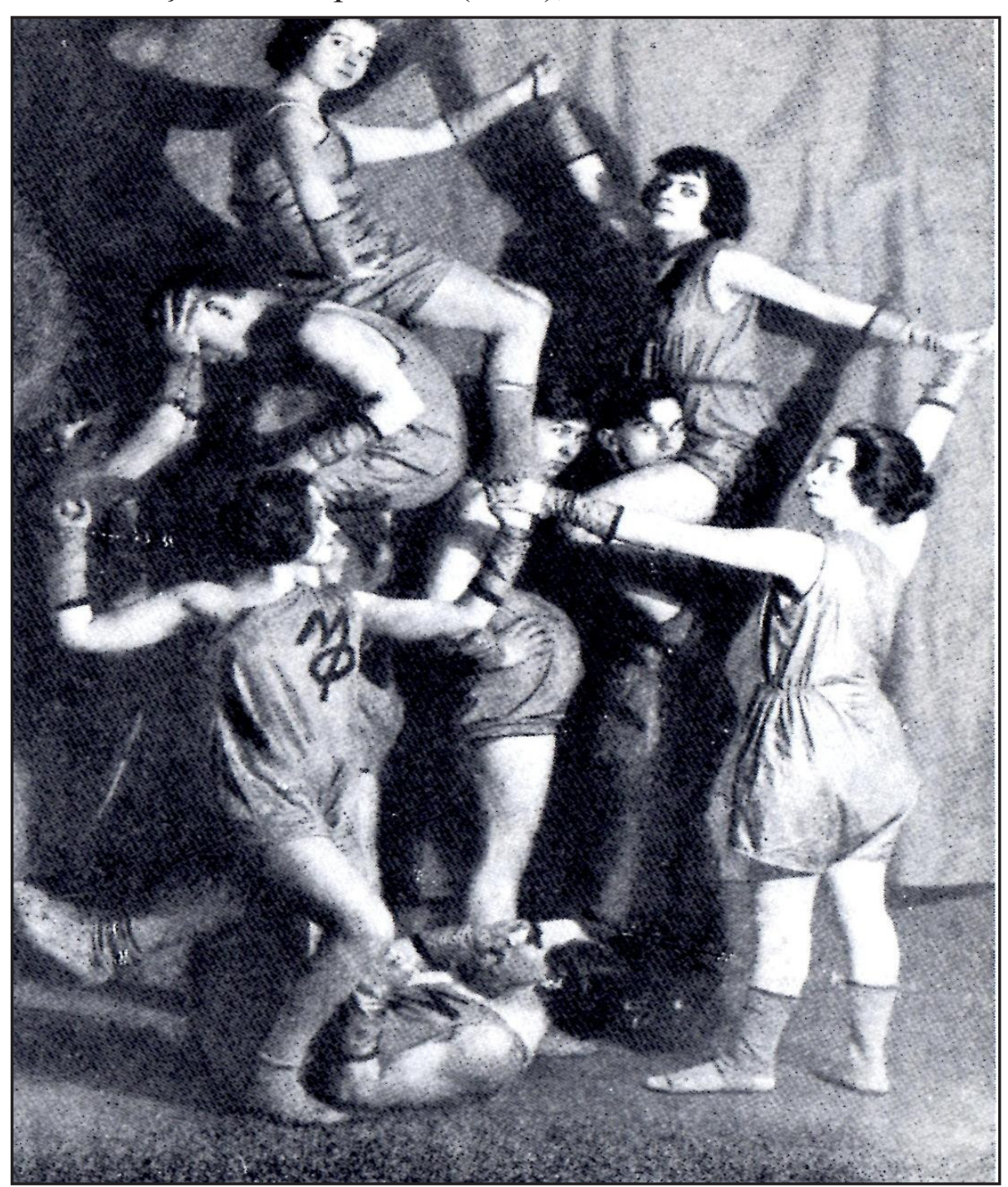

Figura 4 - A dança das máquinas, 1922, ateliê Masfor, realizado por N. Forreger. 
Forreger vai criar e desenvolver um treinamento para os atores e os dançarinos no qual o gesto é movido pelas leis de "direção, movimento e sucessão" (Chtcherbakov, 1996, p. $54)^{53}$. Duplo, ele visa a desenvolver a musculatura corporal (já que o corpo do ator é um instrumento regido pela vontade do intérprete) e aumentar as possibilidades psicofísicas: as impulsões voluntárias, a excitabilidade dos reflexos. Forreger insiste na necessária virtuosidade de todo o corpo, com uma atenção particular dedicada aos ombros, que exprimem um desenho emocional, à coordenação dos movimentos e à precisão. Ele descreve quatro tipos de movimento: geométricos elementares (sob tensão muscular), circulares, ondulatórios (a tensão se dissipa); em espiral (em descontração); angulares e maneiristas (sucessão de tensão e de descontração). O sistema do "tefiztrenaj" é uma gramática do jogo do ator composta de quatrocentos exercícios de base ${ }^{54}$.

Boris Ferdinandov, fundador do Teatro experimental heroico e inventor do metrorritmo ${ }^{55}$, talvez tenha tomado emprestado do sistema delsartiano a focalização sobre o ritmo do discurso. Ele começa seu aprendizado no Teatro de Arte entre 1911 e 1912 e posteriormente se junta ao teatro ambulante de Pavel Gaïdebourov (no qual encontra Georges Pitoëff), entre 1913 e 1914, antes de colaborar, ele também, com Taïrov. Criado em 1921 e fechado um ano mais tarde, seu teatro procura fundamentar racionalmente o ato criador através da pantomima que articula o ritmo e a métrica. Para Édipo Rei de Sófocles, em 1921, Vadim Cherchenevitch, juntamente com o maestro, o acompanhamento musical e o coro, guia os atores nas suas intervenções metrorrítmicas. Os resultados foram pouco convincentes, os movimentos pareciam artificiais, monótonos, convencionais a ponto de serem caricatos ${ }^{56}$. $\mathrm{Na}$ La Cagnotte de Labiche, o discurso se torna recitativo como na opereta, e o cômico resulta da combinação das estruturas metrorrítmicas e não das situações ou dos efeitos. A música está ausente em A dama em luvas negras, de Vadim Cherchenevitch, o temporitmo interior dos atores segue uma partitura de ruídos urbanos (buzinas, sirenes, telefones). Em uma declaração de setembro de 1922, o diretor afirma que as experiências em laboratório 
sobre o movimento do corpo humano no espaço devem levar os trabalhadores do ateliê para além dos limites da $\operatorname{arte}^{57}$.

Entretanto, é incerto, no estado atual das pesquisas, estabelecer vínculos diretos e claros. A pesquisa sobre a influência do sistema Delsarte é ainda recente. A emigração de Volkonski, a campanha contra o formalismo, condenando as vanguardas e, em seguida, a onda anticosmopolita, que excluiu o francês Delsarte das fontes de inspirações possíveis na atuação teatral soviética, fizeram desaparecer elos ou distorceram as cadeias do processo de transmissão. As pesquisas sobre a antropologia do ator são concernentes, até o presente momento, apenas ao cinema, formidável conservatório dos movimentos e das boas e más maneiras. Se desde Marcel Mauss não há mais universalidade da linguagem do corpo, se o corpo biológico deve ser associado ao corpo cultural e ao corpo social, é essencial que sejam relidos os escritos de Delsarte, Stanislavski, M. Tchekhov, Grotowski, inseridos num processo histórico e cultural. E graças a essa grande pesquisa sobre a "fábrica do gesto $^{58 ",}$, ao enfatizar o "gestus", desde Lessing até Brecht, o gesto psicológico e sonoro, as ações físicas, o datílico biomecânico e os movimentos eurítmicos, tornar-se-á essencial o lugar de Delsarte. 


\section{Notas}

${ }^{1}$ Este texto foi preparado para Colloque International François Delsarte-Mémoire et héritages, promovido pelo Institut National d'Histoire de l'Art, em Paris, de 18 a 19 de novembro de 2011, sob a coordenação de Christophe Damour e Franck Waille. Os Anais do Colóquio estão em fase de edição.

2 “Il n'y a pas de courant Delsarte, il y a plutôt une radioactivité Delsarte". Alain Porte, "François Delsarte (1811-1871). Le théâtre et L'Esprit de l'Auteur". In: Les Fondements du mouvement scénique, La Rochelle/Saintes, Rumeur des Âges et Maison de Polichinelle, 1993, p. 13.

${ }^{3}$ Thomas Leabhart, no seu estudo "Misunderstanding Delsarte (and preserving the Cherries)", encontra uma equivalência entre as três forças interiores (centro do pensamento, centro das emoções e centro da ação) identificadas por Bella Merlin em sua obra sobre Stanislavski (2003, p. 71) e a trindade delsartiana do mental, espiritual-emocional e físico. Cf. Mime journal, Essays on François Delsarte, 2004-2005, p. 18. Cf. também, nessa mesma revista, o artigo de George Taylor e Rose Whyman, "François Delsarte, Prince Sergei Volkonski and Mikhail Chekhov", p. 97-111.

${ }^{4}$ Grotowski descobriu Delsarte na Rússia quando lá estudava em 1955. Em Vers un théâtre pauvre, Lausanne, L'Âge d'Homme, 1971, p. 209-210, ele explicava, durante uma conversa em Nova York em 1967, o papel que tivera no início de sua prática o sistema Delsarte, apesar de um viés muito estereotipado.

${ }^{5}$ Alain Porte, "Four Reflexions on François Delsarte", in Mime journal, Essays on François Delsarte, 2004-2005, p. 26.

${ }^{6}$ Cf. a revista Golos i reč, jan. 1913, p. 16, assim como V. Teljakovskij, Dnevniki direktora Imperatorskih teatrov 1901-1903, Skt-Peterburg-Moskva, "Artist.Režisser. Teatr", 2002, p. 480 e 496 e M. Jampol'ski, "Eksperimenty Kulešova i novaja antropologija aktera”, in Noosfera $i$ hudožestvennoe tvorčestvo, Sbornik statej, Moskva, Nauka, 1991, p. 183.

${ }^{7} \mathrm{O}$ dom do ritmo musical é físico por essência. A cada função espiritual corresponde uma função corporal e vice-versa. Cf. Selma Odom, "Delsarte an Traces in Dalcroze Eurythmics", in Mime Journal, Essays on François Delsarte, 2004-2005, p. 137-151.

${ }^{8}$ Durante os últimos ensaios de Hamlet, S. Volkonski leciona cursos de ginástica rítmica, teóricos e práticos para os comediantes do Teatro de Arte: a primeira lição ocorreu no dia 7 de outubro de 1911 de 10h às 11h30. K. Stanislavski, Vassili Katchalov, Ivan Moskvine, Vladimir Gribounine, Olga Knipper-Tchekhova, Maria Germanova, Maria Lilina e outros, em colantes pretos, se esforçam "para executar minuciosamente os exercícios rítmicos, segundo o sistema Dalcroze" no Foyer do Teatro de Arte. Cf. I. Vinogradskaja, Žizn' i tvorčestvo K.S. Stanislavskogo, Letopis', t. 2, Moskva, “Moskovskij Hudožestvennyj teatr”, 2003, p. 304-305. Volkonski se torna sócio do teatro nesse mesmo ano de 1911.

${ }^{9}$ Volkonski realiza a única aplicação de seu ensinamento numa alegoria pantomímica 1914 (criada em 6 de janeiro de 1915), considerada por André Levinson (Apollon, 1915, n. 1, p. 67) como a primeira experiência russa de utilização do método Dalcroze no teatro. 
${ }^{10}$ S. Volkonskij, Vyrazytel'nyj čelovek, Sankt-Peterburg, Apollon, 1913, p. 20.

${ }^{11}$ Em suas memórias, Volkonski conta que Stanislavski lhe pediu para corrigir a dicção dos atores em L'Oiseau bleu, em cartaz desde 1908; porém, ele não obteve êxito, já que os comediantes estavam pouco preparados para suas instruções. Cf. S. Volkonskij, Moi vospominanija, Berlin, Mednyj vsadnik, 1923, p. 325.

${ }^{12}$ K. Stanislavskij, Sobranie sočinenij v 9-ti tomah, t. 3: Rabota aktera nad soboj v tvorčestvom processe voploščenija. Materialy k knige, Moskva, Iskusstvo, 1990, p. 76-77. Cf. também I. Vinogradskaja, Žizn' i tvorčestvo K.S. Stanislavskogo, Letopis', t. 3, Moskva, "Moskovskij Hudožestvennyj teatr", 2003, p. 135 et 205 et Hudožestvennyj teatr. Tvorčeskie ponedel'niki i drugie dokumenty (1916-1919), Moskva, "Moskovskij Hudožestvennyj teatr”, 2006, p. 35, 106, 150, 461, 534, 562, 569.

${ }^{13}$ F. Delsarte, manuscrito inédito, citado por Alain Porte, "François Delsarte (1811-1871). Le théâtre et L'Esprit de l'Auteur", in Les Fondements du mouvement scénique, La Rochelle/ Saintes, Rumeur des Âges et Maison de Polichinelle, 1993, p. 22.

${ }^{14}$ Em fevereiro de 1921, durante a preparação de La Princesse Turandot, espetáculo-farol do Troisième Studio, Volkonski é convidado para formar os alunos nas leis do discurso. Cf. Evgenij Vahtangov, Dokumenty i svidetel'stva, t. 2, sost. V. Ivanov, Moskva, Indrik, 2011, p. 436.

${ }^{15}$ Volkonski, em seus cursos, destaca que os russos, particularmente, devem compreender a importância do ritmo induzindo um recorte (e, portanto, um domínio) do espaço e do tempo, um senso do equilíbrio e da medida, uma economia de movimentos que é uma garantia de eficiência: "A rítmica nos é particularmente útil visto os nossos temperamentos instáveis, nossa vontade fraca e nossos gostos pouco marcados". Cf. S. Volkonskij, Hudožestvennye otkliki, Spb, Apollon, 1912, p. 29.

${ }^{16}$ Deirdre Hurst Du Prey, "Chekhov in England and America", in Wandering stars, Russian Emigré Theatre, 1905-1940, organizado por Laurence Senelick, Iowa City, University of Iowa Press, 1992, p. 162-163.

${ }^{17}$ S. Volkonskij, Vyrazytel'nyj čelovek, Sankt-Peterburg, Apollon, 1913, p. 6.

18 "L'art est la connaissance des procédés extérieurs par lesquels l'homme découvre la vie, l'âme et la raison; [...]. L'art est la découverte du signe qui correspond à l'essence".

${ }^{19}$ Ele cita textos sobre Delsarte, publicados entre os anos 1870 e 1909 (os livros de Florence Adams, Angélique Arnaud, Alfred Giraudet, Anna Morgan, Geneviève Stebbins etc.), e menciona outros trabalhos como esses, de Delsarte, sobre o tema (Le Brun, Ciceron, Hume, Lowe, Riccoboni, Da Vinci, Fénelon, La Feuillée, Ribot, Bertillon).

${ }^{20}$ Ele enumera os alunos famosos (Barbot, Rachel, Viardot, Gounot, Ingres), evoca o interesse de Louis Philippe por Delsarte, relembra que Théophile Gautier o qualificara como "Talma musical", que Lamartine reserva nele a imagem de orador ímpar. Indica ainda que Alfred Giraudet acrescentou ao Sistema de seu mestre a anotação do gesto.

${ }^{21}$ S. Volkonskij, Vyrazytel'nyj čelovek, Sankt-Peterburg, Apollon, 1913, p. 135. 
${ }^{22}$ Volkonski não preconiza o que impunha Delsarte em suas lições (a anedota narrada por um de seus alunos tinha de ser verdadeira): a imitação dos desenhos presos na parede, que representavam as emoções. Cf. Thomas Leabhart, "Misunderstanding Delsarte (and preserving the Cherries)", in Mime journal, Essays on François Delsarte, 2004-2005, p. 14.

${ }^{23}$ S. Volkonskij, Vyrazytel'nyj čelovek, Sankt-Peterburg, Apollon, 1913, p. 151-152.

${ }^{24}$ M. Chekhov, L'Imagination créatrice de l'acteur, Paris, Pygmalion/Roger Watelet, 1996, p. 113. Cf. também meu estudo "Don Quichotte, Le roi Lear ou les rôles rêvés d'un théâtre impossible", in Mikhaïl Tchekhov/Michael Chekhov. De Moscou à Hollywood, du théâtre au cinéma, sob a direção de de M.-C. Autant-Mathieu, Montpellier, L'Entretemps, 2009, p. 169-183.

${ }^{25}$ Delsarte, citado por G. Taylor e R. Whyman, "François Delsarte, Prince Sergei Volkonski and Mikhail Chekhov" in Mime journal, Essays on François Delsarte, 2004-2005, p. 105. Delsarte declara ainda: "Minha ciência é tão estritamente ligada a minhas crenças, que receio, ao vos ver negar a fonte que a fecunda, que esta quente e viva realidade não esteja mais em vossas mãos do que um cadáver". [Ma science est si étroitement liée à mes croyances que j'ai bien peur, en vous voyant nier la source qui la féconde, que cette chaude et vivante réalité ne soit plus dans vos mains qu'un cadavre]; citado por Alain Porte, "François Delsarte (1811-1871). Le théâtre et L'Esprit de l'Auteur", p. 15.

${ }^{26}$ Para uma comparação mais clara, embora pouco convincente, entre M. Tchekhov e Delsarte, inclusive a propósito das noções de forma e de centros centrífugos (excêntricos), centrípetos (concêntricos) ou equilibrados (pausas), tornar-se-á oportuna a leitura do estudo citado de G. Tylor e R. Whyman. Quer seja considerado como um herdeiro longínquo de Delsarte, quer um simples investigador dos domínios espirituais e artísticos, englobando o homem nas forças cósmicas, $\mathrm{M}$. Tchekhov se enquadra numa tentativa de organicidade. Os exercícios não devem ser feitos mecanicamente, mas sim lhes dando sentido e os integrando a uma filosofia do ser num todo que o ultrapassa.

${ }^{27}$ Ele cita Steiner para afirmar: "Se a linguagem deve se tornar plástica por um lado e musical por outro, é necessário antes de tudo que se introduza o gesto na linguagem." [Si le langage doit devenir plastique d'un côté, musical de l'autre, il s'agit alors avant tout d'introduire le geste dans le langage] - M. Chekhov, L'Imagination créatrice de l'acteur, Paris, Pygmalion/ Roger Watelet, 1996, p. 121.

28 "L'acteur bien entraîné et techniquement formé à visualiser et effectuer des gestes psychologiques [...] prend plaisir à cette vie kaléidoscopique et bouillonnante d'images, de gestes et d'intentions [...]". - M. Chekhov, L'Imagination créatrice de l'acteur, Paris, Pygmalion/ Roger Watelet, 1996, p. 114.

29 “L'accord avec la nature : voilà la base du savoir-faire qu'enseigne Delsarte. L'accord avec la nature et non l'accord avec les habitudes établies et les usages de la scène..." - S. Volkonskij, Vyrazytel'nyj čelovek, Sankt-Peterburg, Apollon, 1913, p. 167.

30 "Sur scène, ne pensez pas aux règles et aux lois, elles doivent être en vous, elles auront valeur à condition d'être devenues inconscientes. [...] Plus vous aurez pensé en faisant les exercices, et moins vous aurez à penser pendant la représentation”. - S. Volkonskij, Vyrazytel’nyj čelovek, 
Sankt-Peterburg, Apollon, 1913, p. 9.

${ }^{31}$ S. Volkonskij, Vyrazytel'nyj čelovek, Sankt-Peterburg, Apollon, 1913, p. 46.

32 "Je le reconnais, je redoute de vous le faire lire: le système dont je parle constitue une approche différente de la vôtre. Mais la recherche vise la même chose: la vérité de la vie dans la représentation. S'il peut sembler que la mécanicité domine le sentiment, ce n'est qu'une apparence sans fondement. Regardez les deux derniers chapitres: Un dernier conseil et Conclusion". - Arquivos do Teatro de Arte de Moscou, fonds K. Stanislavski, KS 7628, carta de 18 de fevereiro de 1911.

33 "Je ne considère pas cela comme une superbe gymnastique artistique des organes du corps, appelés à "exprimer". Comment le visage peut-il exprimer ce que je ressens si les muscles [qui le composent] ne se soumettent pas à mon sentiment?" - Arquivos do Teatro de Arte de Moscou, fonds K. Stanislavski, KS 7628, carta de 18 de fevereiro de 1911.

${ }^{34}$ Ted Shawn, Chaque petit mouvement. Sobre François Delsarte, Bruxelles, Editions Complexe et Centre national de la danse, 2005, p. 40.

${ }^{35}$ S. Volkonskij, Vyrazytel'nyj čelovek, Sankt-Peterburg, Apollon, 1913, p.33. O ombro é a zona da emoção, o cotovelo, do estado afetivo, o punho e o polegar, do sentimento e da vontade.

${ }^{36}$ Cf. Ja. Apuškin, "Delsart v Rossii”, in Ekran, 1922, n. 23, p. 9. Esse artigo é um dos raros, talvez o único a evocar diretamente Delsarte após a Revolução.

${ }^{37}$ Le GITIS: Instituto do Estado de Arte Teatral.

38 "Au lieu de la théorie du ressenti et du jeu avec les "tripés" qui conduisent (par méconnaissance de la construction du corps humain) à des effusions psychologiques, l'Institut théâtral créera un modèle d'homme organisé en formant l'acteur aux sciences exactes, en développant et entraînant l'intellect d'un côté, et par la voie du sport et de la biomécanique de l'autre [...]'. Ejzenštejn o Mejerhol'de, 1919-1948, Moskva, Novoe izdatel'stvo, 2005, p. 127.

${ }^{39}$ Como afirma Lev Obolenski, eles partem do livro de Volkonski e do autor ele mesmo, que ensinava o sistema Delsarte. Cf. Oksana Bulgakova, Fabrika žestov, Moskva, NLO, 2005, p. 39-40.

${ }^{40}$ Cf. M. Jampol'skij, "Eksperimenty Kulešova i novaja antropologija aktera", in Noosfera $i$ hudožestvennoe tvorčestvo, Moskva, Nauka, 1991, p. 190.

${ }^{41}$ Cf. M. Jampol'skij, "Eksperimenty Kulešova i novaja antropologija aktera", in Noosfera i hudožestvennoe tvorčestvo, Moskva, Nauka, 1991, p. 190.

42 "Le corps est l'instrument, l'acteur est l'instrumentaliste". - S. Volkonskij, Vyrazytel'nyj čelovek, Sankt-Peterburg, Apollon, 1913, p. 35.

${ }^{43}$ S. Volkonskij, Vyrazytel'nyj čelovek, Sankt-Peterburg, Apollon, 1913, p. 132, em nota. O fim da nota é "esquecido" pelos leitores dos anos de 1920: "Entretanto, é essencial lembrar-se disso: se seguirdes apenas a mecânica sem o sentimento (ou sem o sentido), isso resultará em uma caricatura da vida; e se representardes o sentimento com uma falsa mecânica, isso não resultará em nada, já que a vida estará ausente". 
${ }^{44}$ Ejzenštejn o Mejerhol'de, 1919-1948, Moskva, Novoe izdatel'stvo, 2005, p. 87.

${ }^{45}$ Ejzenštejn o Mejerhol'de, 1919-1948, Moskva, Novoe izdatel'stvo, 2005, p. 114 e 116. Meyerhold tira seus exemplos da Commedia dell'Arte, refere-se à super-marionete de Craig e cita ainda a atuação dos atores franceses, Sarah Bernhardt et Coquelin (dos quais toma emprestado a fórmula da biomecânica $\mathrm{N}=\mathrm{A} 1+\mathrm{A} 2)$. Cf. Mnemozina. Dokumenty i fakty iz istorii otečestvennogo teatra XX veka, vyp.2, pod red. V. Ivanov, Moskva, URSS, 2000, p. 282.

${ }^{46}$ Mnemozina. Dokumenty i fakty iz istorii otečestvennogo teatra XX veka, red. V. Ivanov, Moskva, Indrik, 2009, p. 697, 735-736.

${ }^{47}$ Sobre as origens da biomecânica geral e da biomecânica teatral, confira-se o admirável artigo de Irina Sirotkina, "Biomehanika: meždu naukoj i iskusstvom”, in VIET, 2011, n. 1, p. 46-70.

${ }^{48}$ A. Miliakh, “Teorija novoj antropologii aktera i stat'ja S.Ejzenštejna i S. Tret'jakova 'Vyrazytel'noe dviženije", in Mnemozina. Dokumenty i fakty iz istorii otečestvennogo teatra XX veka, vyp.2, pod red. V. Ivanov, Moskva, URSS, 2000, p. 287.

${ }^{49}$ Zapiski režissera, 1921, traduzido em francês por C. Amiard-Chevrel, Le Théâtre libéré, Lausanne, L'Âge d'Homme-La Cité, 1974, p. 63. Em uma crítica impiedosa contra o jogo dos atores do Théâtre de Chambre, Meyerhold, curiosamente vai opor à agitação tediosa, à gestualidade toda em círculos bizarros e em elipses dos comediantes de Taïrov, o rigor de um Delsarte que preconiza uma passada firme, posições, movimentos do corpo, um rosto em correspondência com as emoções a serem transmitidas. Cf. Meyerhold, Ecrits sur le théâtre, t.2, trad. B. Picon-Vallin, Lausanne, L’Âge d'Homme, 2009 (réed.), p. 119.

${ }^{50}$ I. Sokolov citado por D. Boult (John Bowlt), "Dvigaj svoe telo! Ippolit Sokolov i teorija dvigatel'noj kul'tury", in Iskusstvo dviženija. Istorija i sovremennost', Moskva, GCTM im. Bahrušina, 2002, p. 14.

51 "Le théâtre peut nous apprendre à marcher et à gesticuler, à parler une nouvelle langue économe, précise, catégorique, efficace. Le théâtre est la fabrique du style de notre époque". - I. Sokolov, 1922, citado por Jurij Civjan, Na podstupah k karpalistike. Dviženie $i$ žest v literature, iskusstve i kino, Moskva, NLO, 2010, p. 135.

52 "Sim, nós estamos às vésperas de uma nova cotidianidade, às vésperas de uma nova iniciativa taylorizada, econômica, às vésperas de uma gesticulação utilitária, às vésperas de uma nova construção de vestimentas e sapatos, de cadeiras e mesas. O teatro pode e deve ensinar a todos a andar e a gesticular de forma taylorizada, a falar uma nova língua taylorizada, econômica, oficial e técnica. Em nossa época de industrialismo, uma cultura do gesto taylorizado no trabalho, na vida, na ginástica e na arte é imprescindível. Agora, o que necessitamos? A plástica ou a gesticulação? Delsarte e, sobretudo, Duncan descobriram o movimento emocional da plástica grega. Todavia, agora, no teatro e na coreografia, deve-se ter apenas um gesto desnudo, formal".

53 “Teatral'nye manifesty Nikolaja Forregera", dossiê apresentado por Vadim Chtcherbakov, in Mnemozina. Dokumenty i fakty iz istorii otečestvennogo teatra XX veka, pod red. V. Ivanov, 1996, p. 54.

${ }^{54}$ Confira o dossiê “Teatral'nye manifesty Nikolaja Forregera”, dossiê apresentado por Vadim 
Chtcherbakov, in Mnemozina, Mnemozina. Dokumenty i fakty iz istorii otečestvennogo teatra XX veka, pod red. V. Ivanov, 1996, p. 45-78.

${ }^{55} \mathrm{Cf}$. o artigo de V. Ivanov, "Ritmometričeskij teatr Borisa Ferdinandova", in Iskusstvo dviženija. Istorija i sovremennost', Moskva, GCTM im. Bahrušina, 2002, p. 65-76.

${ }^{56}$ I. Sokolov, cité par M. Jampol'skij, in “Eksperimenty Kulešova i novaja antropologija aktera”, in Noosfera i hudožestvennoe tvorčestvo, Moskva, Nauka, 1991, p. 196.

${ }^{57}$ V. Ivanov, "Bunt marginala. Analitičeskij teatr Borisa Ferdinandova", in Mnemozina. Dokumenty i fakty iz istorii otečestvennogo teatra XX veka, pod red. V. Ivanova, 1996, p. 232.

${ }^{58}$ Tal é o título da obra citada de Oksana Bulgakova. 


\section{Referências}

APUŠKIN, Ja. Delsart v Rossii. Ekran, n. 23, p. 9, 1922.

AUTANT-MATHIEU, Marie-Christine. Don Quichotte, Le roi Lear ou les rôles rêvés d'un théâtre impossible. In: AUTANT-MATHIEU, Marie-Christine (Org.). Mikhaïl Tchekhov/ Michael Chekhov. De Moscou à Hollywood, du théâtre au cinema. Montpellier: L'Entretemps, 2009. P. 169-183.

BULGAKOVA, Oksana. Fabrika žestov. Moskva: NLO, 2005.

CHEKHOV, Michael. L'Imagination Créatrice de l'Acteur. Paris: Pygmalion/Roger Watelet, 1996.

CHTCHERBAKOV, Vadim. Teatral'nye manifesty Nikolaja Forregera. In: IVANOV, Vladislav (Org.). Mnemozina. Dokumenty i fakty iz istorii otečestvennogo teatra XX veka, 1996. P. 45-78.

CIVJAN, Jurij. Na Podstupah k Karpalistike. Dviženie i žest v literature, iskusstve i kino. Moskva: NLO, 2010.

DU PREY, Deirdre Hurst. Chekhov in England and America. In: SENELICK, Laurence (Org.).

Wandering Stars, Russian Emigré Theatre, 1905-1940. Iowa City: University of Iowa Press, 1992, P. 162-163.

ĖJZENŠTEJN, Sergei. Ejzenštejn o Mejerhol'de, 1919-1948. ZABRODIN, Vladimir. (Org.). Moskva: Novoe izdatel'stvo, 2005.

GROTOWSKI, Jerzy. Vers un Théâtre Pauvre. Lausanne: L’Âge d'Homme, 1971.

IVANOV, Vladislav. Ritmometričeskij Teatr Borisa Ferdinandova. In: KLIM, T. (Org.). Iskusstvo Dviženija. Istorija i sovremennost'. Moskva: GCTM im. Bahrušina, 2002. P. 65-76.

IVANOV, Vladislav (Org.). Mnemozina. Dokumenty i fakty iz istorii otečestvennogo teatra XX veka, vyp. 2. Moskva: Ėditorial URSS, 2000.

JAMPOL'SKIJ, M. Eksperimenty Kulešova i Novaja Antropologija Aktera. Noosfera i Hudožestvennoe Tvorčestvo. Sbornik statej, Moskva: Nauka, 1991.

KLIM, T. (Org.). Dvigaj svoe telo! Ippolit Sokolov i teorija dvigatel'noj kul'tury. Iskusstvo Dviženija. Istorija i sovremennost'. Moskva: GCTM im. Bahrušina, 2002. P. 9-19.

LEABHART, Thomas. Misunderstanding Delsarte (and preserving the Cherries). In: Essays on François Delsarte, 2004-2005. Mime Journal, Pomona College, Claremont, 2005.

MERLIN, Bella. Konstantin Stanislavsky. London: Routledge, 2003.

MEYERHOLD, Vsevolod. Ecrits sur le Théâtre, t. 2. Tradução B. Picon-Vallin. Lausanne: L'Âge d'Homme, 2009.

MILIAKH, A. Teorija novoj antropologii aktera i stat'ja S.Ejzenštejna i S. Tret'jakova 'Vyrazytel'noe dviženije. In: IVANOV, Vladislav (Org.). Mnemozina. Dokumenty i fakty iz istorii otečestvennogo teatra XX veka, vyp. 2. Moskva: Ėditorial URSS, 2000.

ODOM, Selma. Delsarte an Traces in Dalcroze Eurythmics. In: Essays on François Delsarte, 2004-2005. Mime Journal, Pomona College, Claremont, 2005. P. 137-151.

PORTE, Alain. Les Fondements du Mouvement Scénique: François Delsarte (1811-1871). Le 
Théâtre et L'Esprit de l'Auteur. In: ACTES DU COLLOQUE INTERNATIONAL DANS LE CADRE DE LA MAISON DE POLICHINELLE À SAINTES. 1991. La Rochelle/Saintes: Rumeur des Âges et Maison de Polichinelle, 1993. P. 13-28.

PORTE, Alain. Four Reflexions on François Delsarte. In: Essays on François Delsarte, 20042005. Mime Journal, Pomona College, Claremont, 2005.

SHAWN, Ted. Chaque Petit Mouvement. Sobre François Delsarte. Bruxelles: Editions Complexe et Centre national de la danse, 2005.

SIROTKINA, Irina. Biomehanika: meždu naukoj i iskusstvom. VIET, n. 1, p. 46-70, 2011.

STANISLAVSKIJ, Konstantin. Sobranie sočinenij v 9-ti tomah, t. 3. In: STANISLAVSKIJ, Konstantin. Rabota Aktera nad Soboj v Tvorčestvom Processe Voploščenija. Materialy k knige. Moskva: Iskusstvo, 1990.

TAYLOR, George; WHYMAN, Rose. François Delsarte, Prince Sergei Volkonski and Mikhail Chekhov. In: Essays on François Delsarte, 2004-2005. Mime Journal, Pomona College, Claremont, 2005. P. 97-111.

TELJAKOVSKIJ, V. Dnevniki Direktora Imperatorskih Teatrov 1901-1903. Skt-PeterburgMoskva: Artist. Režisser. Teatr, 2002.

VAHTANGOV, Evgenij. Dokumenty i Svidetel'stva, t. 2, sost. V. Ivanov, Moskva: Indrik, 2011.

VINOGRADSKAJA, Irina. Žizn' i Tvorčestvo K.S. Stanislavskogo, Letopis, t. 2. Moskva: Moskovskij Hudožestvennyj teatr, 2003.

VINOGRADSKAJA, Irina. Žizn' i Tvorčestvo K.S. Stanislavskogo, Letopis, t. 3. Moskva: Moskovskij Hudožestvennyj teatr, 2003.

VOLKONSKIJ, Sergueï. Carta de 18 de fevereiro de 1911 endereçada a Konstantin Stanislavskij. Arquivos do Teatro de Arte de Moscou, fonds K. Stanislavski, KS 7628.

VOLKONSKIJ, Sergueï. Vyrazytel’nyj čelovek. Sankt-Peterburg: Apollon, 1913.

VOLKONSKIJ, Sergueï. Moi Vospominanija. Berlin: Mednyj vsadnik, 1923

VOLKONSKIJ, Sergueï. Hudožestvennye Otkliki. Spb: Apollon, 1912.

Marie-Christine Autant-Mathieu é pesquisadora no CNRS - Centre National de la Recherche Scientifique e professora na Université Sorbonne Nouvelle Paris III, em Paris, na França. É especialista em teatro Russo e tem artigos e livros publicados em várias línguas.

E-mail: autant.mathieu@wanadoo.fr

Traduzido do original em francês por Nadia Nacif Campany Neves (Universidade Federal Fluminense - UFF) e revisado por Dominique Marie Philippe Geneviève Boxus (Universidade Federal Fluminense - UFF).

Recebido em 24 de dezembro de 2011

Aprovado em 17 de agosto de 2012 